\title{
Synthesis and Characterisation of Molecular Polarised-Covalent Thorium-Rhenium and -Ruthenium Bonds
}

\author{
Joseph P. A. Ostrowski, Ashley J. Wooles and Stephen T. Liddle*
}

check for updates

Citation: Ostrowski, J.P.A.; Wooles,

A.J.; Liddle, S.T. Synthesis and Characterisation of Molecular Polarised-Covalent ThoriumRhenium and -Ruthenium Bonds. Inorganics 2021, 9, 30. https:// doi.org/10.3390/inorganics 9050030

Academic Editor: Duncan H. Gregory

Received: 13 April 2021

Accepted: 20 April 2021

Published: 21 April 2021

Publisher's Note: MDPI stays neutral with regard to jurisdictional claims in published maps and institutional affiliations.

Copyright: (c) 2021 by the authors. Licensee MDPI, Basel, Switzerland. This article is an open access article distributed under the terms and conditions of the Creative Commons Attribution (CC BY) license (https:// creativecommons.org/licenses/by/ $4.0 /)$.
Department of Chemistry, The University of Manchester, Oxford Road, Manchester M13 9PL, UK; joe-ostrowski@outlook.com (J.P.A.O.); ashley.wooles@manchester.ac.uk (A.J.W.)

* Correspondence: steve.liddle@manchester.ac.uk; Tel.: +44-161-275-4612

Abstract: Separate reactions of $\left[\mathrm{Th}\left\{\mathrm{N}\left(\mathrm{CH}_{2} \mathrm{CH}_{2} \mathrm{NSiMe}_{2} \mathrm{Bu}^{\mathrm{t}}\right)_{2}\left(\mathrm{CH}_{2} \mathrm{CH}_{2} \mathrm{NSi}(\mathrm{Me})\left(\mathrm{Bu}^{\mathrm{t}}\right)\left(\mu-\mathrm{CH}_{2}\right)\right]_{2}\right.\right.$ (1) with $\left[\mathrm{Re}\left(\eta^{5}-\mathrm{C}_{5} \mathrm{H}_{5}\right)_{2}(\mathrm{H})\right](2)$ or $\left[\mathrm{Ru}\left(\eta^{5}-\mathrm{C}_{5} \mathrm{H}_{5}\right)(\mathrm{H})(\mathrm{CO})_{2}\right]$ (3) produced, by alkane elimination, $\left[\mathrm{Th}\left(\operatorname{Tren}^{\mathrm{DMBS}}\right) \operatorname{Re}\left(\eta^{5}-\mathrm{C}_{5} \mathrm{H}_{5}\right)_{2}\right]\left(\right.$ ThRe, Tren $\left.{ }^{\mathrm{DMBS}}=\left\{\mathrm{N}\left(\mathrm{CH}_{2} \mathrm{CH}_{2} \mathrm{NSiMe}_{2} \mathrm{Bu}^{\mathrm{t}}\right)_{3}\right\}^{3-}\right)$, and $\left[\mathrm{Th}\left(\operatorname{Tren}^{\mathrm{DMBS}}\right) \mathrm{Ru}\right.$ $\left.\left(\eta^{5}-\mathrm{C}_{5} \mathrm{H}_{5}\right)(\mathrm{CO})_{2}\right]$ (ThRu), which were isolated in crystalline yields of $71 \%$ and $62 \%$, respectively. Complex ThRe is the first example of a molecular Th-Re bond to be structurally characterised, and ThRu is only the second example of a structurally authenticated Th-Ru bond. By comparison to isostructural U-analogues, quantum chemical calculations, which are validated by IR and Raman spectroscopic data, suggest that the Th-Re and Th-Ru bonds reported here are more ionic than the corresponding U-Re and U-Ru bonds.

Keywords: thorium; rhenium; ruthenium; metal-metal bonds; uranium; density functional theory

\section{Introduction}

The field of metal-metal bonds is mature and vast with many applications [1-5]. Whilst homopolymetallic $\mathrm{d}$ transition metal systems dominate this still burgeoning field [1-3], heteropolymetallic derivatives have been gaining prominence [3-5]. Where actinide elements are concerned, in the absence of isolable homopolymetallic species under normal conditions [6], a growing number of heteropolymetallic derivatives have been isolated and characterised [7-11], including Th and $U$ complexes exhibiting bonds to d transition metals such as Mo [12], Fe [13-19], Ru [13,14,19,20], Re [21-23], Co [24-26], Rh [27-29], Ni [30-35], $\mathrm{Pd}$ [31], Pt [31,36], Cu [37,38], and Ag [39], and p main group metals and metalloids such as $\mathrm{Al}[40,41], \mathrm{Ga}[41,42], \mathrm{Si}[43-46], \mathrm{Ge}$ [47], Sn [48,49], Sb [50], and Bi [50-52].

For some time now we have had an interest in the study of f-block-metal bonds, but most of our efforts have focussed on the synthesis and characterisation of U-derivatives. Of particular pertinence to this paper are the U-Re and U-Ru complexes [U(Tren $\left.{ }^{\mathrm{DMBS}}\right) \operatorname{Re}\left(\eta^{5}\right.$ $\left.\mathrm{C}_{5} \mathrm{H}_{5}\right)_{2}$ ] (URe) [22] and [U(Tren $\left.{ }^{\mathrm{DMBS}}\right) \mathrm{Ru}\left(\eta^{5}-\mathrm{C}_{5} \mathrm{H}_{5}\right)(\mathrm{CO})_{2}$ ] (URu) [20], respectively (Tren ${ }^{\mathrm{DMBS}}$ $\left.=\left\{\mathrm{N}\left(\mathrm{CH}_{2} \mathrm{CH}_{2} \mathrm{NSiMe}_{2} \mathrm{Bu}^{\mathrm{t}}\right)_{3}\right\}^{3-}\right)$. During our studies, we noted that there are no examples of structurally authenticated molecular Th-Re complexes to date, and that there is only one example of a structurally characterised Th-Ru complex, namely, $\left[\mathrm{Th}\left(\eta^{5}-\mathrm{C}_{5} \mathrm{Me}_{5}\right)_{2}(\mathrm{I}) \mathrm{Ru}\left(\eta^{5}-\right.\right.$ $\left.\mathrm{C}_{5} \mathrm{H}_{5}\right)(\mathrm{CO})_{2}$ ] (I) reported by Marks in 1985 [19]. Since URe and URu had proven to be accessible by salt and alkane elimination strategies [20,22], we sought to prepare and characterise the corresponding Th-derivatives so that comparisons between Th and U could be made.

Here, we report the synthesis and characterisation of two new Th-complexes that exhibit bonds to Re and $\mathrm{Ru}$ and compare them to the previously reported U-congeners. We find that these Th-complexes exhibit more ionic Th-Re/-Ru bonds than the U-analogues; by validating quantum chemical calculations with spectroscopic vibrational data, we have identified the strength of these Th-Re/-Ru bonds indirectly using Ru-carbonyls as reporters, and we have probed the Th-Re and Th-Ru bonds directly using Raman spectroscopy. 


\section{Results and Discussion}

\subsection{Synthesis and Isolation of the Th-Re and Th-Ru Complexes ThRe and ThRu}

Treatment of the colourless thorium-cyclometallate complex [Th $\left\{\mathrm{N}\left(\mathrm{CH}_{2} \mathrm{CH}_{2} \mathrm{NSiMe}_{2}\right.\right.$ $\left.\mathrm{Bu}^{\mathrm{t}}\right)_{2}\left(\mathrm{CH}_{2} \mathrm{CH}_{2} \mathrm{NSi}(\mathrm{Me})\left(\mathrm{Bu}^{\mathrm{t}}\right)\left(\mu-\mathrm{CH}_{2}\right)\right]_{2}$ (1) [53] with two equivalents of the pale yellow rhenium complex $\left[\mathrm{Re}\left(\eta^{5}-\mathrm{C}_{5} \mathrm{H}_{5}\right)_{2}(\mathrm{H})\right](2)$ [54] in toluene, Scheme 1, afforded a dark yellow solution. Work-up afforded yellow crystals of the Th-Re complex [Th(Tren $\left.\left.{ }^{\text {DMBS }}\right) \operatorname{Re}\left(\eta^{5}-\mathrm{C}_{5} \mathrm{H}_{5}\right)_{2}\right]$ (ThRe) in $71 \%$ isolated yield. Thus, as was found for analogous uranium chemistry, ${ }^{22}$ alkane elimination is an effective method for constructing thorium-metal bonds.

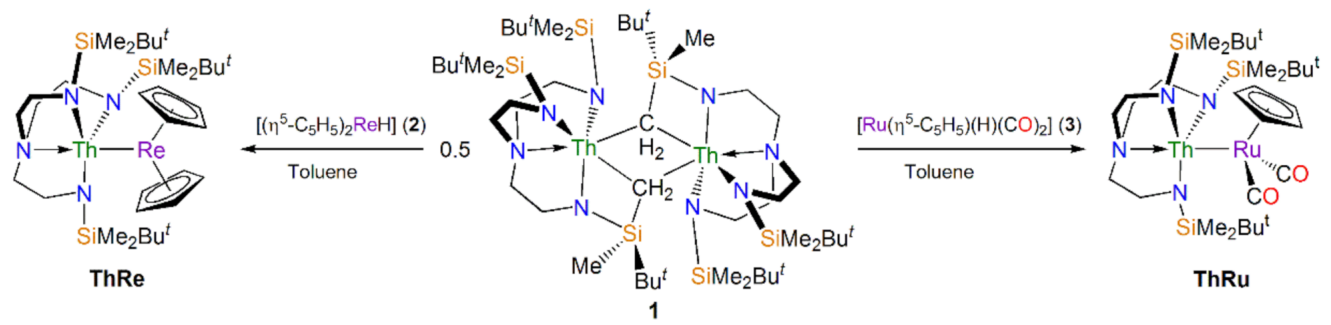

Scheme 1. Synthesis of ThRe and ThRu from 1, 2, and 3, respectively.

Encouraged by the successful synthesis of ThRe by alkane elimination, we also treated 1 with two equivalents of the yellow ruthenium complex $\left[\mathrm{Ru}\left(\eta^{5}-\mathrm{C}_{5} \mathrm{H}_{5}\right)(\mathrm{H})(\mathrm{CO})_{2}\right]$ (3) [55] in benzene, Scheme 1. Subsequent removal of the reaction mother liquor from the resulting pale yellow precipitate and recrystallisation afforded the Th-Ru complex [Th(Tren $\left.{ }^{\text {DMBS }}\right) \mathrm{Ru}\left(\eta^{5}-\mathrm{C}_{5} \mathrm{H}_{5}\right)(\mathrm{CO})_{2}$ ] (ThRu), isolated as light brown crystals of the benzene solvate in $62 \%$ yield.

\subsection{Solid-State Structures of the Th-Re and Th-Ru Complexes ThRe and ThRu}

The solid-state structures of $\mathbf{T h R e}$ and $\mathrm{ThR} \mathbf{u}$ were determined by X-ray Diffraction, Figure 1. The structure of ThRe, Figure 1a, confirms the anticipated trigonal bipyramidal thorium ion and Th-Re bond, which is the first example of a molecular Th-Re bond. The Th-Re distance is found to be 3.1117(2) A. By definition there are no other Th-Re bonds for comparison, but this distance is marginally $(\sim 0.05 \AA)$ longer than the sum of the single covalent bond radii and Th and $\operatorname{Re}(3.06 \AA)$ [56], and is $\sim 0.06 \AA$ longer than the U-Re distance of 3.0479(6) $\AA$ in URe [22], which is in-line with the different single bond covalent

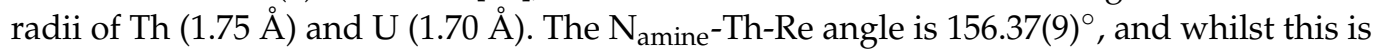
approximately trans in nature, the deviation perhaps reflects that the DMBS substituents allow the Tren ${ }^{\text {DMBS }}$ unit to flex from $C_{3}$ symmetry towards a $C_{s}$ symmetry to accommodate the rhenocene fragment. All other distances and angles are unremarkable.

The structure of ThRu, Figure $1 b$, confirms the presence of a Th-Ru bond and thus the absence of any isocarbonyl linkages. The Th-Ru distance is found to be 3.1227(3) $\AA$, which compares to a value of $3.00 \AA$ for the sum of the single bond covalent radii of Th and $\mathrm{Ru}$ [56]. There is only one other example of a molecular Th-Ru bond, which is I reported in 1985, that exhibits a Th-Ru distance of 3.0277(6) $\AA$ [19]. Thus, the Th-Ru distance in ThRu can be considered to be long, likely reflecting charge polarisation into the Ru-CO back-bonding orbitals rendering the $\mathrm{Ru}$ a poorer donor site than the Re in rhenocene; support for this comes from the spectroscopic data (see below) and the fact that the U-Ru distance of 3.0739(2) $\AA$ in URu is $\sim 0.05 \AA$ shorter, in-line with the respective metal single bond covalent radii [56]. The $\mathrm{Ru}-\mathrm{C}_{\mathrm{CO}}$ and $\mathrm{C}-\mathrm{O}$ distances in $\mathrm{ThRu}$ average 1.844(4) and $1.165(4) \AA$, respectively. The latter is slightly longer than the C-O distance in free CO $(1.128 \AA)$, and the $\mathrm{Ru}-\mathrm{C}_{\mathrm{CO}}$ and $\mathrm{C}-\mathrm{O}$ distances are similar to the analogous distances in URu [20]. The $\mathrm{N}_{\text {amine }}$-Th-Ru angle is $156.60(6)^{\circ}$, which is rather similar to the $\mathrm{N}_{\text {amine }}-\mathrm{Th}-\mathrm{Re}$ angle in ThRe. 
a)

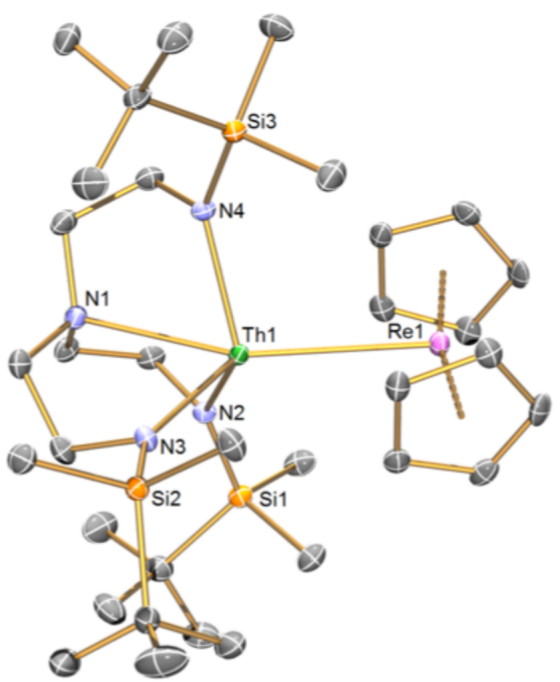

b)

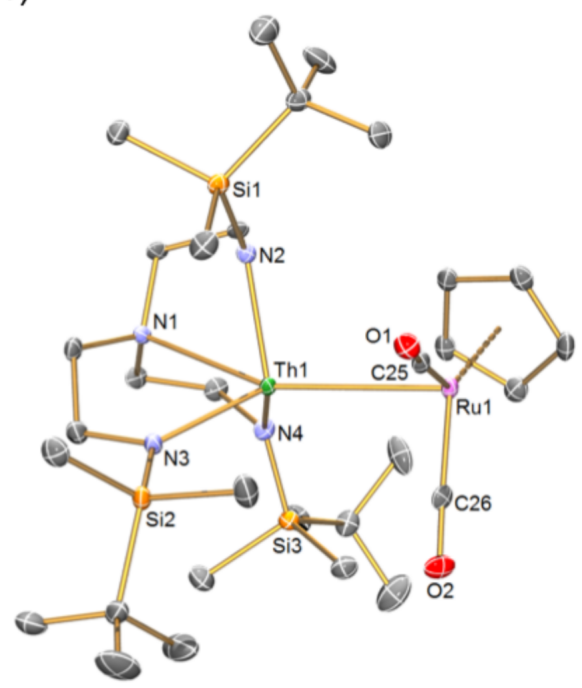

Figure 1. Solid-state structures of (a) ThRe and (b) ThRu at $150 \mathrm{~K}$ with displacement ellipsoids set to $30 \%$. Hydrogen atoms, disorder components, and benzene lattice solvent for $\mathbf{T h R u}$ are omitted for clarity.

\subsection{Spectroscopic and Analytical Characterisation of the Th-Re and Th-Ru Complexes ThRe and $\mathrm{ThR} u$}

The ${ }^{1} \mathrm{H}$ and ${ }^{13} \mathrm{C}\left\{{ }^{1} \mathrm{H}\right\}$ NMR spectra of $\mathbf{T h R e}$ and ThRu exhibit resonances in the ranges 0-4 and 0-5 ppm, consistent with the diamagnetic, closed-shell formulations of Th(IV) and the Re and Ru ions. The NMR spectra of $\mathbf{T h R e}$ and $\mathbf{T h R u}$ are largely as anticipated, though the CO C-resonances for ThRu and Cp C-resonances could not be located despite extensive attempts to locate them. The NMR and IR data for ThRe and ThRu do not provide any evidence for hydrides, and their isostructural natures compared to the corresponding U-complexes support the view that there are not any hydrides in ThRe and ThRu.

The IR spectrum of ThRu exhibits strong carbonyl absorptions at 1943 and $1869 \mathrm{~cm}^{-1}$, which can be compared to those of URu $\left(1944,1872 \mathrm{~cm}^{-1}\right)$ [20], I $\left(1968,1900 \mathrm{~cm}^{-1}\right){ }^{19}$ and $\left[\mathrm{Th}\left(\eta^{5}-\mathrm{C}_{5} \mathrm{H}_{5}\right)_{3} \mathrm{Ru}\left(\eta^{5}-\mathrm{C}_{5} \mathrm{H}_{5}\right)(\mathrm{CO})_{2}\right]\left(1915,1847 \mathrm{~cm}^{-1}\right)$ [13]. It can thus be noted that there is more Ru-CO back-bonding in ThRu compared to I [19] but less than $\left[\mathrm{Th}\left(\eta^{5}-\mathrm{C}_{5} \mathrm{H}_{5}\right)_{3} \mathrm{Ru}\left(\eta^{5}-\right.\right.$ $\left.\mathrm{C}_{5} \mathrm{H}_{5}\right)(\mathrm{CO})_{2}$ ] [13], which would be expected to render the Ru-centre in $\mathbf{T h R u}$ a weaker donor; in that scenario, a longer Th- Ru bond would be predicted in ThRu compared to I, which is the only other Th-Ru complex to be structurally characterised, and that is indeed the experimental observation. These data suggest that the $\left[\mathrm{Th}\left(\operatorname{Tren}^{\mathrm{DMBS}}\right)\right]^{+}$ fragment is slightly more electron-deficient than $\left[\mathrm{Th}\left(\eta^{5}-\mathrm{C}_{5} \mathrm{H}_{5}\right)_{3}\right]^{+}$, since an An-fragment that polarises charge from the Ru-component most will deplete the extent of Ru-CO back-bonding the most resulting in a higher $\mathrm{CO}$ stretching frequency. Conversely, the exchange for a $\mathrm{Cp}$ ligand for iodide, even with two cyclopentadienyl ligands replaced by the more strongly donating pentamethylcyclopentadienyl ligand, renders $\left[\mathrm{Th}\left(\eta^{5}-\mathrm{C}_{5} \mathrm{Me}_{5}\right)_{2}(\mathrm{I})\right]^{+}$ the most electron deficient fragment. The magnitude of the shift of the asymmetric $\mathrm{CO}$ stretching frequency to high frequency compared to $\left[\mathrm{Ru}\left(\eta^{5}-\mathrm{C}_{5} \mathrm{H}_{5}\right)(\mathrm{CO})_{2}\right]^{-}\left(1749 \mathrm{~cm}^{-1}\right)$ reveals a shift of $120 \mathrm{~cm}^{-1}$ [20], which is lower than the shift observed for group 4-group 8 bonds (140-150 $\mathrm{cm}^{-1}$ ) [4] but higher than for analogous lanthanide-group 8 bonds $\left(110 \mathrm{~cm}^{-1}\right)[4,8,10]$, suggesting that the Th-Ru linkage in $\mathbf{T h R u}$ is more covalent than lanthanide analogues but still largely dominated by ionic character.

We also recorded Raman spectra of $\mathbf{T h R e}$ and $\mathbf{T h R u}$, and of most pertinence are inelastic scattering bands at $103 / 136$ and $112 \mathrm{~cm}^{-1}$, respectively. On the basis of analytical frequencies calculations on $\mathbf{T h R u}$ and $\mathbf{T h R u}$ (see below), these are assigned as corresponding to Th-Re and Th-Ru stretches, respectively. For comparison, the W-W stretch 
for $\left[\mathrm{W}_{2}(\mathrm{CO})_{10}\right]\left[\mathrm{K}(18 \text {-crown-6)(THF })_{2}\right]$ was recently reported to be found at $97 \mathrm{~cm}^{-1}$ by Raman spectroscopy [57].

\subsection{Quantum Chemical Computational Analysis of the Th-Re and Th-Ru Complexes ThRe and ThRu}

In order to probe the Th-Re/-Ru linkages in ThRe and ThRu, we performed scalar relativistic DFT calculations on the full structures of these two complexes. The optimised gas-phase geometries (see Supplementary Materials for final coordinates and energies) compare well to the experimental solid-state structures, for example, returning Th-Re and Th-Ru distances of 3.1293 and $3.1139 \AA$, which are in excellent agreement with the experimental values of 3.1117(2) and 3.1227(3) $\AA$. We therefore conclude that the computed models of ThRe and ThRu provide qualitative and representative models of the electronic structures of these complexes.

The computed MDC-q charges for the two Th, Re, and Ru ions in ThRe and ThRu are $1.87,1.41,0.38$, and 0.71 , respectively. These values can be compared to the two $\mathrm{U}$, $\mathrm{Re}$, and Ru values of $1.88,1.50,0.38$, and 0.67 [20,22], respectively, for the analogous Ucomplexes, showing negligible variations. The calculated Nalewajski-Mrozek Th-Re and Th-Ru bond orders for ThRe and ThRu are 0.72 and 0.52. Interestingly, in contrast to the largely invariant computed charges, the calculated bond orders for ThRe and $T h R u$ are lower than for URe and URu, which have computed bond orders of 1.13 and 0.76 , respectively $[20,22]$, suggesting more ionic metal-metal bonds for the thorium complexes compared to the uranium ones. For comparison, the Th- $\mathrm{N}_{\text {amide }}$ and Th- $\mathrm{N}_{\text {amine }}$ bond orders are calculated to average 0.95 and 0.28 . The $\mathrm{Ru}-\mathrm{C}_{\mathrm{CO}}$ and $\mathrm{C}-\mathrm{O}$ bond orders for ThRu average 1.24 and 2.32, respectively, reflecting the back-bonding of electron density from $\mathrm{Ru}$ to $\mathrm{C}$ with concomitant reduction of the $\mathrm{CO}$ bond order from 3 in free $\mathrm{CO}$.

The HOMO-1 and HOMO-2 for complex ThRe represent the principal possible Th-Re bonding interactions on symmetry grounds, Figure 2a,b. HOMO-2 constitutes the ThRe $\sigma$-bond, being derived from the $2 \mathrm{a}_{1}$ orbital from bent metallocene molecular orbital considerations. HOMO-2 contains only 5.9\% Th-character, compared to $10.8 \%$ U-character in the isostructural U-derivative [22]. HOMO-1 is the corresponding $b_{2}$ orbital, but unlike the U-analogue which shows a $\pi$-bond, in ThRe this MO remains largely localised on the rhenocene fragment ( $<2 \%$ Th character, of $9.9 \% \mathrm{U}$ character in the U-analogue). Together, these observations nicely account for the reduced Th-Re bond order compared to the larger U-Re bond order in the isostructural U-congener [22]. The HOMO of ThRe is the $1 \mathrm{a}_{1}$ orbital, and it is essentially non-bonding with respect to the Th-Re bonding interaction; the energy ordering of the $1 a_{1}, b_{2}$, and $2 a_{1}$ orbitals in ThRe can thus be related to the degree of stabilisation afforded to those orbitals by how strongly they donate to the Th ion in ThRe.

a)

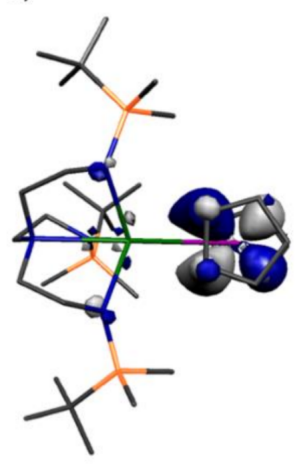

b)

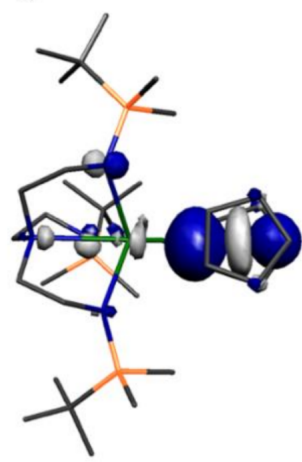

c)

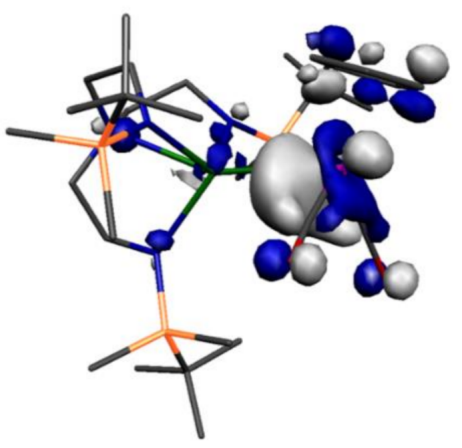

Figure 2. (a) HOMO-1 (252, $-4.054 \mathrm{eV})$ of ThRe. (b) HOMO-2 $(251,-4.161 \mathrm{eV})$ of ThRe. (c) HOMO $(234,-4.409 \mathrm{eV})$ of ThRu. Hydrogen atoms are omitted for clarity.

The HOMO of ThRu represents the Th-Ru interaction, Figure 2c. As found analogously for $\mathbf{U R u}$ [20], this $\mathrm{MO}$ is $\left[\mathrm{Ru}\left(\eta^{5}-\mathrm{C}_{5} \mathrm{H}_{5}\right)(\mathrm{CO})_{2}\right]$-centred $(60 \%)$, with $\sim 29 \% 4 \mathrm{~d}$ character, 
and 9.6 and $5.8 \% 5 \mathrm{p}$ and 5 s character, respectively, with the remaining $15.6 \%$ involving the $\mathrm{CO} \pi^{*}$ orbital coefficients. The rest of this $\mathrm{MO}$ is delocalised over the Tren ${ }^{\mathrm{DMBS}}$ ligand or Th $(0.7 \%)$, revealing a largely ionic Th-Ru interaction and one where the CO stretching frequency is confirmed as a reporter of the Th-Ru bonding interaction, as discussed above.

Lastly, an analytical frequencies calculation predicts $\mathrm{CO}$ stretching frequencies of 1924 and $1864 \mathrm{~cm}^{-1}$ for $\mathbf{T h R u}$, which are in excellent agreement with the experimentally observed values of 1943 and $1869 \mathrm{~cm}^{-1}$. This experimental confirmation of the accuracy of the DFT calculations then permits us to address the Th-Re and Th-Ru bond vibrations in ThRe and ThRu. The Th-Ru stretch for $\mathbf{T h R u}$ is computed to occur at $126 \mathrm{~cm}^{-1}$, which is in good agreement with the corresponding experimental Raman value of $112 \mathrm{~cm}^{-1}$. The Th-Re stretch of ThRe appears to be split by coupling to other vibrational modes, principally characterised by bands computed at 107 and $138 \mathrm{~cm}^{-1}$, which compares to experimentally observed bands at 103 and $136 \mathrm{~cm}^{-1}$.

\section{Materials and Methods}

\subsection{General Materials and Methods}

All manipulations were carried out using Schlenk techniques, or an MBraun UniLab glovebox, under an atmosphere of dry nitrogen. Solvents were dried by passage through activated alumina towers and degassed before use. Deuterated solvents were dried over $\mathrm{NaK}_{2}$, distilled, and stored over $\mathrm{NaK}_{2}$. Crystals were examined using either a Rigaku FR-X diffractometer, equipped with a HyPix $6000 \mathrm{HE}$ photon counting pixel array detector with mirror-monochromated $\mathrm{Cu} \mathrm{K} \alpha(\lambda=1.5418 \AA)$ radiation or a Rigaku Xcalibur2 diffractometer, equipped with an Atlas CCD area detector and a sealed tube source with graphite-monochromated Mo $\mathrm{K} \alpha$ radiation $(\lambda=0.71073 \AA)$. Intensities were integrated from a sphere of data recorded on narrow $\left(1.0^{\circ}\right)$ frames by $\omega$ rotation. Cell parameters were refined from the observed positions of all strong reflections in each data set. Gaussian grid face-indexed absorption corrections with a beam profile correction were applied. The structures were solved by dual methods, and all non-hydrogen atoms were refined by full-matrix least-squares on all unique $\mathrm{F}^{2}$ values with anisotropic displacement parameters with exceptions noted in the respective cif files. Except where noted, hydrogen atoms were refined with constrained geometries and riding thermal parameters. CrysAlisPro [58] was used for control and integration, SHELXT [59] was used for structure solution, and SHELXL [60] and Olex2 [61] were employed for structure refinement. ORTEP-3 [62] and POV-Ray [63] were employed for molecular graphics. FTIR spectra were recorded on a Bruker Alpha spectrometer with Platinum-ATR module. A Horiba XploRA Plus Raman microscope with a $638 \mathrm{~nm}$ laser (power: $\leq 150 \mathrm{~mW}$ ) was used to obtain all Raman spectra. The power of the laser was adjusted for each sample using a filter to prevent sample decomposition. Elemental microanalyses were carried out by Mr Martin Jennings at the Micro Analytical Laboratory, Department of Chemistry, The University of Manchester. Complexes 1-3 were prepared as described previously [53-55].

\subsection{Quantum Chemical Calculations}

Geometry optimisations for ThRe and ThRu were performed using coordinates derived from their respective crystal structures as the starting points. No constraints were imposed on the structures during the geometry optimisations. The calculations were performed using the Amsterdam Density Functional (ADF) suite version 2017 with standard convergence criteria [64,65]. The DFT geometry optimisations employed Slater type orbital (STO) triple- $\zeta$-plus polarisation all electron basis sets (from the Dirac and ZORA/TZP database of the ADF suite). Scalar relativistic approaches (spin-orbit neglected) were used within the ZORA Hamiltonian [66-68] for the inclusion of relativistic effects, and the local density approximation (LDA) with the correlation potential due to Vosko et al. was used in all of the calculations [69]. Generalised gradient approximation corrections were performed using the functionals of Becke and Perdew [70,71]. MOLEKEL [72] was used to prepare 
the three-dimensional plots of the electron density. Frequencies were computed using the analytical frequencies routine in ADF.

\subsection{Preparation of $\left[\mathrm{Th}\left(\mathrm{Tren}^{\mathrm{DMBS}}\right) \mathrm{ReC} \mathrm{p}_{2}\right](\mathrm{ThRe})$}

Toluene $(20 \mathrm{~mL})$ was added to a precooled $\left(-78^{\circ} \mathrm{C}\right)$ mixture of $1(0.359 \mathrm{~g}, 0.25 \mathrm{mmol})$ and $2(0.154 \mathrm{~g}, 0.5 \mathrm{mmol})$. The resultant pale-yellow suspension was allowed to warm to RT and then stirred for $16 \mathrm{~h}$, giving a dark yellow solution. Volatiles were removed in vacuo, and the resulting brown solid was extracted into toluene, concentrated to $5 \mathrm{~mL}$, and cooled to $-30{ }^{\circ} \mathrm{C}$ to afford ThRe as pale brown crystals. Yield: $0.260 \mathrm{~g}, 71 \%$. Anal. Calc'd for $\mathrm{C}_{34} \mathrm{H}_{67} \mathrm{~N}_{4} \mathrm{ReSi}_{3}$ Th: $\mathrm{C} 39.48 ; \mathrm{H} 6.53 ; \mathrm{N} 5.42 \%$. Found: C 39.48; H 6.67; N 5.40\%. ${ }^{1} \mathrm{H}$ NMR $\left(\mathrm{C}_{6} \mathrm{D}_{6}\right) \delta: 4.42(10 \mathrm{H}, \mathrm{s}, \mathrm{Cp}-\mathrm{H}), 3.21\left(6 \mathrm{H}, \mathrm{t}, \mathrm{CH}_{2}\right), 2.45\left(6 \mathrm{H}, \mathrm{t}, \mathrm{CH}_{2}\right), 1.09\left(27 \mathrm{H}, \mathrm{s}, \mathrm{CH}_{3}\right), 0.38$ $\left(18 \mathrm{H}, \mathrm{s}, \mathrm{CH}_{3}\right)$ ppm. ${ }^{13} \mathrm{C}\left\{{ }^{1} \mathrm{H}\right\}$ NMR $\left(\mathrm{C}_{6} \mathrm{D}_{6}\right) \delta: 67.93\left(\mathrm{CH}_{2}\right), 46.65\left(\mathrm{CH}_{2}\right), 28.90\left(\mathrm{C}-\mathrm{CH}_{3}\right), 21.96$ $\left(\mathrm{C}-\mathrm{CH}_{3}\right),-1.78\left(\mathrm{Si}_{-} \mathrm{CH}_{3}\right)$ ppm. FTIR $v / \mathrm{cm}^{-1}$ (ATR): $2950(\mathrm{w}), 2850(\mathrm{~m}), 1462(\mathrm{~m}), 1245(\mathrm{~m})$, 1058 (m), 929 (s), 805 (s). Raman $v / \mathrm{cm}^{-1}$ (Neat, $\left.\leq 15 \mathrm{~mW}\right): 3103$ (m, br), 2952 (m), 2853 (m), $1084(\mathrm{~s}), 567(\mathrm{~m}), 338(\mathrm{~s}), 136(\mathrm{w}), 103(\mathrm{w})$, and $63(\mathrm{~s})$.

\subsection{Preparation of $\left[\mathrm{Th}\left(\operatorname{Tren}^{\mathrm{DMBS}}\right) \mathrm{RuCp}-(\mathrm{CO})_{2}\right](\mathrm{ThR} \boldsymbol{u})$}

Benzene $(10 \mathrm{~mL})$ was added to a mixture of $1(0.210 \mathrm{~g}, 0.15 \mathrm{mmol})$ and $3(0.067 \mathrm{~g}$, $0.30 \mathrm{mmol}$ ) in a glovebox. The resultant light brown solution quickly gave a pale-yellow precipitate, which was separated from the solution, washed with pentane $(2 \times 5 \mathrm{~mL})$, and allowed to dry. The solid was extracted into minimal THF, which afforded ThRu as pale brown crystals; these crystals were found to be the benzene solvate ThRu. $\mathrm{C}_{6} \mathrm{H}_{6}$, but drying under vacuum results in their desolvation, as reflected by the other characterisation data. Yield: $0.152 \mathrm{~g}, 62 \%$. Anal. Calc'd for $\mathrm{C}_{31} \mathrm{H}_{62} \mathrm{~N}_{4} \mathrm{O}_{2} \mathrm{RuSi}_{3}$ Th: C 39.60; $\mathrm{H} 6.65 ; \mathrm{N} 5.96 \%$. Found: C 39.45; H 6.70; N 5.36\%. ${ }^{1} \mathrm{H}$ NMR $\left(\mathrm{C}_{6} \mathrm{D}_{6}\right) \delta: 5.08(5 \mathrm{H}, \mathrm{s}, \mathrm{Cp}-\mathrm{H}), 3.20\left(6 \mathrm{H}, \mathrm{t}, J_{\mathrm{HH}}=\right.$ $\left.4.96 \mathrm{~Hz}, \mathrm{CH}_{2}\right), 2.38\left(6 \mathrm{H}, \mathrm{t}, \mathrm{J}_{\mathrm{HH}}=4.96 \mathrm{~Hz}, \mathrm{CH}_{2}\right), 1.04\left(27 \mathrm{H}, \mathrm{s}, \mathrm{C}-\mathrm{CH}_{3}\right), 0.51\left(18 \mathrm{H}, \mathrm{s}, \mathrm{Si}^{-\mathrm{CH}_{3}}\right)$

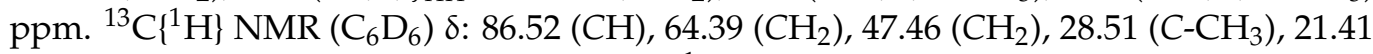
$\left(\mathrm{C}-\mathrm{CH}_{3}\right),-3.25\left(\mathrm{Si}-\mathrm{CH}_{3}\right) \mathrm{ppm}$. FTIR $\mathrm{v} / \mathrm{cm}^{-1}$ (ATR): $2924(\mathrm{w}), 2848(\mathrm{w}), 1943(\mathrm{~s}), 1869(\mathrm{~s})$, $1462(\mathrm{w}), 1248(\mathrm{~m}), 1072(\mathrm{~m}), 936(\mathrm{~m})$. Raman $v / \mathrm{cm}^{-1}$ (Neat, $\left.\leq 15 \mathrm{~mW}\right): 2957(\mathrm{~m}), 2853(\mathrm{~s})$, $1935(\mathrm{~s}), 1869(\mathrm{~s}), 1200(\mathrm{~s}), 1102(\mathrm{~s}), 567(\mathrm{~s}), 518(\mathrm{~s}), 303(\mathrm{~s}), 112(\mathrm{~m})$, and $73(\mathrm{~s})$.

\section{Conclusions}

To conclude, we have prepared two new triamidoamine complexes of Th that possess Th-Re and Th-Ru bonds using an alkane elimination strategy. The Th-Re bond in ThRe is the first structurally authenticated example of a molecular Th-Re bond, and the Th-Ru bond in ThRu is only the second example of a structurally characterised Th-Ru bond, with the other example reported 36 years ago. Structural, spectroscopic, and computational characterisation of these two complexes, along with comparisons to previously reported isostructural U-Re and U-Ru complexes, has permitted an analysis of these metal-metal bonds. In-line with the current understanding, these Th-metal bonds are like-for-like more ionic than the U-congeners. By being able to experimentally validate the calculations using spectroscopic vibrational data, as well as gauging the strength of these metal-metal bonds indirectly using the carbonyls as reporters, we have been able to probe with certainty the Th-Re and Th-Ru bonds directly using Raman spectroscopy.

Supplementary Materials: The following are available online at https:/ / www.mdpi.com/article/ 10.3390/inorganics9050030/s1, Table S1: Final Coordinates and Energy from a Single Point Energy Calculation on Geometry Optimised ThRe, Table S2: Final Coordinates and Energy from a Single Point Energy Calculation on Geometry Optimised ThRu. CIFs and checkCIF output files for ThRe and ThRu. 
Author Contributions: Conceptualisation, S.T.L.; methodology, S.T.L. and J.P.A.O.; formal analysis, J.P.A.O. and A.J.W.; investigation, J.P.A.O.; data curation, A.J.W.; writing—original draft preparation, S.T.L.; writing-review and editing, S.T.L., J.P.A.O., and A.J.W.; supervision, S.T.L.; project administration, S.T.L.; funding acquisition, S.T.L. All authors have read and agreed to the published version of the manuscript.

Funding: We thank the Royal Society (UF071260, UF110005, and RG080285), EPSRC (EP/G051763/1, EP/M027015/1, and EP/P001386/1), ERC (StG23921 and CoG612724), and The University of Manchester for funding and support, and the Alexander von Humboldt Foundation for the award of a Friedrich Wilhelm Bessel Research Award to S.T.L.

Institutional Review Board Statement: Not applicable.

Informed Consent Statement: Not applicable.

Data Availability Statement: The crystallographic data for ThRe and ThRu have been deposited with the Cambridge Crystallographic Data Centre, CCDC numbers 2076926 and 2076927, and all other data are available from the authors on request.

Conflicts of Interest: The authors declare no conflict of interest. The funders had no role in the design of the study; in the collection, analyses, or interpretation of data; in the writing of the manuscript; or in the decision to publish the results.

\section{References}

1. Cotton, F.A.; Murillo, C.A.; Walton, R.A. (Eds.) Multiple Bonds between Metal Atoms, 3rd ed.; Springer: New York, NY, USA, 2005.

2. Parkin, G. (Ed.) Metal-Metal Bonding; Springer: New York, NY, USA, 2010.

3. Liddle, S.T. (Ed.) Molecular Metal-Metal Bonds: Compounds, Synthesis, Properties; Wiley VCH: Weinheim, Germany, 2015.

4. Wheatley, N.; Kalck, P. Structure and Reactivity of Early-Late Heterobimetallic Complexes. Chem. Rev. 1999, 99, 3379-3420. [CrossRef] [PubMed]

5. Chipman, J.A.; Berry, J.F. Paramagnetic Metal-Metal Bonded Heterometallic Complexes. Chem. Rev. 2020, 120, 2409-2447. [CrossRef] [PubMed]

6. Zhang, X.; Wang, Y.; Morales-Martínez, R.; Zhong, J.; de Graaf, C.; Rodríguez-Fortea, A.; Poblet, J.M.; Echegoyen, L.; Feng, L.; Chen, N. $\mathrm{U}_{2} @ \mathrm{I}_{\mathrm{h}}(7)-\mathrm{C}_{80}$ : Crystallographic Characterization of a Long-Sought Dimetallic Actinide Endohedral Fullerene. J. Am. Chem. Soc. 2018, 140, 3907-3915. [CrossRef] [PubMed]

7. Liddle, S.T.; Mills, D.P. Metal-Metal Bonds in f-Element Chemistry. Dalton Trans. 2009, 5592-5605. [CrossRef]

8. Oelkers, B.; Butovskii, M.V.; Kempe, R. f-Element-Metal Bonding and the Use of the Bond Polarity to Build Molecular Intermetalloids. Chem. Eur. J. 2012, 18, 13566-13579. [CrossRef]

9. Patel, D.; Liddle, S.T. f-Element-Metal Bond Chemistry. Rev. Inorg. Chem. 2012, 32, 1-22. [CrossRef]

10. Butovskii, M.V.; Kempe, R. Rare earth-metal bonding in molecular compounds: Recent advances, challenges, and perspectives. New J. Chem. 2015, 39, 7544-7558. [CrossRef]

11. Réant, B.L.L.; Liddle, S.T.; Mills, D.P. f-Element silicon and heavy tetrel chemistry. Chem. Sci. 2020, 11, 10871-10886. [CrossRef]

12. Ayres, A.J.; Zegke, M.; Ostrowski, J.P.A.; Tuna, F.; McInnes, E.J.L.; Wooles, A.J.; Liddle, S.T. Actinide-transition metal bonding in heterobimetallic uranium- and thorium-molybdenum paddlewheel complexes. Chem. Commun. 2018, 54, 13515-13518. [CrossRef]

13. Sternal, R.S.; Marks, T.J. Actinide-to-transition metal bonds. Synthesis, characterization, and properties of metal-metal bonded systems having the tris(cyclopentadienyl)actinide fragment. Organometallics 1987, 6, 2621-2623. [CrossRef]

14. Nolan, S.P.; Porchia, M.; Marks, T.J. Organo-f-element thermochemistry. Actinide-Group 14 element and actinidetransition-element bond disruption enthalpies and stoichiometric/catalytic chemical implications thereof in heterobimetallic tris(cyclopentadienyl)uranium(IV) compounds. Organometallics 1991, 10, 1450-1457. [CrossRef]

15. Bucaille, A.; Le Borgne, T.; Ephritikhine, M.; Daran, J.C. Synthesis and X-ray Crystal Structure of a Urana[1]ferrocenophane, the First Tris(1,1'-ferrocenylene) Metal Compound. Organometallics 2000, 19, 4912-4914. [CrossRef]

16. Monreal, M.J.; Carver, C.T.; Diaconescu, P.L. Redox processes in a uranium bis $\left(1,1^{\prime}\right.$-diamidoferrocene) complex. Inorg. Chem. 2007, 46, 7226-7228. [CrossRef]

17. Monreal, M.J.; Diaconescu, P.L. A weak interaction between iron and uranium in uranium alkyl complexes supported by ferrocene diamide ligands. Organometallics 2008, 27, 1702-1706. [CrossRef]

18. Fortier, S.; Aguilar-Calderon, J.R.; Vlaisavljevich, B.; Metta-Magana, A.J.; Goos, A.G.; Botez, C.E. An N-Tethered Uranium(III) Arene Complex and the Synthesis of an Unsupported U-Fe Bond. Organometallics 2017, 36, 4591-4599. [CrossRef]

19. Sternal, R.S.; Brock, C.P.; Marks, T.J. Metal-metal bonds involving actinides. Synthesis and characterization of a complex having an unsupported actinide to transition metal bond. J. Am. Chem. Soc. 1985, 107, 8270-8272. [CrossRef]

20. Gardner, B.M.; Patel, D.; Cornish, A.D.; McMaster, J.; Lewis, W.; Blake, A.J.; Liddle, S.T. The Nature of Unsupported UraniumRuthenium Bonds: A Combined Experimental and Theoretical Study. Chem. Eur. J. 2011, 17, 11266-11273. [CrossRef] 
21. Gardner, B.M.; McMaster, J.; Lewis, W.; Liddle, S.T. Synthesis and structure of $\left\{\mathrm{N}_{(}\left(\mathrm{CH}_{2} \mathrm{CH}_{2} \mathrm{NSiMe}_{3}\right)_{3}\right\} \mathrm{URe}\left(\eta^{5}-\mathrm{C}_{5} \mathrm{H}_{5}\right)_{2}: \mathrm{A}$ heterobimetallic complex with an unsupported uranium-rhenium bond. Chem. Commun. 2009, 2851-2853. [CrossRef]

22. Gardner, B.M.; McMaster, J.; Moro, F.; Lewis, W.; Blake, A.J.; Liddle, S.T. An Unsupported Uranium-Rhenium Complex Prepared by Alkane Elimination. Chem. Eur. J. 2011, 17, 6909-6912. [CrossRef]

23. Patel, D.; King, D.M.; Gardner, B.M.; McMaster, J.; Lewis, W.; Blake, A.J.; Liddle, S.T. Structural and theoretical insights into the perturbation of uranium-rhenium bonds by dative Lewis base ancillary ligands. Chem. Commun. 2011, 47, 295-297. [CrossRef]

24. Patel, D.; Moro, F.; McMaster, J.; Lewis, W.; Blake, A.J.; Liddle, S.T. A Formal High Oxidation State Inverse-Sandwich Diuranium Complex: A New Route to f-Block-Metal Bonds. Angew. Chem. Int. Ed. 2011, 50, 10388-10392. [CrossRef]

25. Napoline, J.W.; Kraft, S.J.; Matson, E.M.; Fanwick, P.E.; Bart, S.C.; Thomas, C.M. Tris(phosphinoamide)-Supported UraniumCobalt Heterobimetallic Complexes Featuring Co $\rightarrow$ U Dative Interactions. Inorg. Chem. 2013, 52, 12170-12177. [CrossRef] [PubMed]

26. Ward, A.L.; Lukens, W.W.; Lu, C.C.; Arnold, J. Photochemical Route to Actinide-Transition Metal Bonds: Synthesis, Characterization and Reactivity of a Series of Thorium and Uranium Heterobimetallic Complexes. J. Am. Chem. Soc. 2014, 136, 3647-3654. [CrossRef]

27. Lu, E.; Wooles, A.J.; Gregson, M.; Cobb, P.J.; Liddle, S.T. A Very Short Uranium(IV)-Rhodium(I) Bond with Net Double-Dative Bonding Character. Angew. Chem. Int. Ed. 2018, 57, 6587-6591. [CrossRef]

28. Hlina, J.A.; Wells, J.A.L.; Pankhurst, J.R.; Love, J.B.; Arnold, P.L. Uranium rhodium bonding in heterometallic complexes. Dalton Trans. 2017, 46, 5540-5545. [CrossRef]

29. Geng, G.; Zhang, M.; Wang, P.; Wang, S.; Maron, L.; Zhu, C. Identification of a uranium-rhodium triple bond in a heterometallic cluster. Proc. Natl. Acad. Sci. USA 2019, 116, 17654-17658.

30. Ritchey, J.M.; Zozulin, A.J.; Wrobleski, D.A.; Ryan, R.R.; Wasserman, H.J.; Moody, D.C.; Paine, R.T. An organothorium-nickel phosphido complex with a short thorium-nickel distance. The structure of $\mathrm{Th}\left(\eta^{5}-\mathrm{C}_{5} \mathrm{Me}_{5}\right)_{2}\left(\mu-\mathrm{PPh}_{2}\right)_{2} \mathrm{Ni}(\mathrm{C})(\mathrm{CO})_{2}$. J. Am. Chem. Soc. 1985, 107, 501-503. [CrossRef]

31. Hlina, J.A.; Pankhurst, J.R.; Kaltsoyannis, N.; Arnold, P.L. Metal-Metal Bonding in Uranium-Group 10 Complexes. J. Am. Chem. Soc. 2016, 138, 3333-3345. [CrossRef] [PubMed]

32. Camp, C.; Toniolo, D.; Andrez, J.; Pecaut, J.; Mazzanti, M. A versatile route to homo- and hetero-bimetallic 5f-5f and $3 \mathrm{~d}-5 \mathrm{f}$ complexes supported by a redox active ligand framework. Dalton Trans. 2017, 46, 11145-11148. [CrossRef]

33. Kozimor, S.A.; Bartlett, B.M.; Rinehart, J.D.; Long, J.R. Magnetic exchange coupling in chloride-bridged 5f-3d heterometallic complexes generated via insertion into a Uranium(IV) dimethylpyrazolate dimer. J. Am. Chem. Soc. 2007, 129, 10672-10674 [CrossRef]

34. Feng, G.; Zhang, M.; Shao, S.; Wang, X.; Wang, S.; Maron, L.; Zhu, C. Transition-metal-bridged bimetallic clusters with multiple uranium-metal bonds. Nat. Chem. 2019, 11, 248-253. [CrossRef] [PubMed]

35. Feng, G.; McCabe, K.N.; Wang, S.; Maron, L.; Zhu, C. Construction of heterometallic clusters with multiple uranium-metal bonds by using dianionic nitrogen-phosphorus ligands. Chem. Sci. 2020, 11, 7585-7592. [CrossRef]

36. Hay, P.J.; Ryan, R.R.; Salazar, K.V.; Wrobleski, D.A.; Sattelberger, A.P. Synthesis and x-ray structure of $\left(\mathrm{C}_{5} \mathrm{Me}_{5}\right)_{2} \mathrm{Th}(\mu-$ $\left.\mathrm{PPh}_{2}\right)_{2} \mathrm{Pt}\left(\mathrm{PMe}_{3}\right)$ : A complex with a thorium-platinum bond. J. Am. Chem. Soc. 1986, 108, 313-315. [CrossRef]

37. Leverd, P.C.; Lance, M.; Nierlich, M.; Vigner, J.; Ephritikhine, M. Synthesis and crystal structure of homoleptic uranium hexathiolates: $\left[\mathrm{NEt}_{2} \mathrm{H}_{2}\right]_{2}\left[\mathrm{U}(\mathrm{SPh})_{6}\right]$ and $\left[\left(\mathrm{Ph}_{3} \mathrm{P}\right) \mathrm{Cu}(\mu-\mathrm{SPh})_{3}-\mathrm{U}(\mu-\mathrm{SPh})_{3} \mathrm{Cu}\left(\mathrm{PPh}_{3}\right)\right]$. J. Chem. Soc. Dalton Trans. 1994, $3563-3567$. [CrossRef]

38. Yang, P.; Zhou, E.; Hou, G.; Zi, G.; Ding, W.; Walter, M.D. Experimental and Computational Studies on the Formation of Thorium-Copper Heterobimetallics. Chem. Eur. J. 2016, 22, 13845-13849. [CrossRef]

39. Fortier, S.; Walensky, J.R.; Wu, G.; Hayton, T.W. High-Valent Uranium Alkyls: Evidence for the Formation of $\mathrm{U}^{\mathrm{VI}}\left(\mathrm{CH}_{2} \mathrm{SiMe}_{3}\right)_{6}$. J. Am. Chem. Soc. 2011, 133, 11732-11743. [CrossRef]

40. Minasian, S.G.; Krinsky, J.L.; Williams, V.A.; Arnold, J. A heterobimetallic complex with an unsupported Uranium(III)Aluminum(I) bond: $\left(\mathrm{CpSiMe}_{3}\right)_{3} \mathrm{U}-\mathrm{AlCp}^{*}\left(\mathrm{Cp}^{*}=\mathrm{C}_{5} \mathrm{Me}_{5}\right)$. J. Am. Chem. Soc. 2008, 130, 10086-10087. [CrossRef]

41. Minasian, S.G.; Krinsky, J.L.; Rinehart, J.D.; Copping, R.; Tyliszczak, T.; Janousch, M.; Shuh, D.K.; Arnold, J. A Comparison of 4f vs $5 \mathrm{f}$ Metal-Metal Bonds in $\left(\mathrm{CpSiMe}_{3}\right)_{3} \mathrm{M}-\mathrm{ECP}^{*}\left(\mathrm{M}=\mathrm{Nd}, \mathrm{U} ; \mathrm{E}=\mathrm{Al}, \mathrm{Ga} ; \mathrm{Cp}^{*}=\mathrm{C}_{5} \mathrm{Me}_{5}\right)$ : Synthesis, Thermodynamics, Magnetism, and Electronic Structure. J. Am. Chem. Soc. 2009, 131, 13767-13783. [CrossRef]

42. Liddle, S.T.; McMaster, J.; Mills, D.P.; Blake, A.J.; Jones, C.; Woodul, W.D. $\sigma$ and $\pi$ Donation in an Unsupported Uranium-Gallium Bond. Angew. Chem. Int. Ed. 2009, 48, 1077-1080. [CrossRef]

43. Diaconescu, P.L.; Odum, A.L.; Agapie, T.; Cummins, C.C. Uranium-Group 14 Element Single Bonds: Isolation and Characterization of a Uranium(IV) Silyl Species. Organometallics 2001, 20, 4993-4995. [CrossRef]

44. Porchia, M.; Brianese, N.; Casellato, U.; Ossola, F.; Rossetto, G.; Zanella, P. Tri(n-cyclopentadienyl)uranium(IV) silyl and siloxide compounds: Crystal structure of $\left[\mathrm{U}\left(\eta^{5}-\mathrm{C}_{5} \mathrm{H}_{5}\right)_{3}\left(\mathrm{OSiPh}_{3}\right)\right]$ : Insertion of Isocyanide into a uranium-silicon bond. J. Chem. Soc. Dalton Trans. 1989, 677-681. [CrossRef]

45. Brackbill, I.J.; Douair, I.; Lussier, D.J.; Boreen, M.A.; Maron, L.; Arnold, J. Synthesis and Structure of Uranium-Silylene Complexes. Chem. Eur. J. 2020, 26, 2360-2364. [CrossRef]

46. Réant, B.L.L.; Berryman, V.E.J.; Seed, J.A.; Basford, A.R.; Formanuik, A.; Wooles, A.J.; Kaltsoyannis, N.; Liddle, S.T.; Mills, D.P. Polarised Covalent Thorium(IV)- and Uranium(IV)-Silicon Bonds. Chem. Commun. 2020, 56, 12620-12623. [CrossRef] 
47. Porchia, M.; Ossola, F.; Rossetto, G.; Zanella, P.; Brianese, N. Synthesis of triscyclopentadienyl(triphenylgermyl)uranium and facile isonitrile insertion into the uranium-germanium bond. J. Chem. Soc. Chem. Commun. 1987, 550-551. [CrossRef]

48. Porchia, M.; Casellato, U.; Ossola, F.; Rossetto, G.; Zanella, P.; Graziani, R. Synthesis and crystal structure of triscyclopentadienyl(triphenyltin)uranium: The first example of a uranium-tin bond. J. Chem. Soc. Chem. Commun. 1986, 1034-1035. [CrossRef]

49. Winston, M.S.; Batista, E.R.; Yang, P.; Tondreau, A.M.; Boncella, J.M. Extending Stannyl Anion Chemistry to the Actinides: Synthesis and Characterization of a Uranium-Tin Bond. Inorg. Chem. 2016, 55, 5534-5539. [CrossRef]

50. Rookes, T.M.; Wildman, E.P.; Balazs, G.; Gardner, B.M.; Wooles, A.J.; Gregson, M.; Tuna, F.; Scheer, M.; Liddle, S.T. ActinidePnictide (An-Pn) Bonds Spanning Non-Metal, Metalloid, and Metal Combinations (An = U, Th; Pn = P, As, Sb, Bi). Angew. Chem. Int. Ed. 2018, 57, 1332-1336. [CrossRef]

51. Lichtenberger, N.; Wilson, R.J.; Eulenstein, A.R.; Massa, W.; Clérac, R.; Weigend, F.; Dehnen, S. Main Group Metal-Actinide Magnetic Coupling and Structural Response Upon $\mathrm{U}^{4+}$ Inclusion into Bi, Tl/Bi, or Pb/Bi Cages. J. Am. Chem. Soc. 2016, 138, 9033-9036. [CrossRef]

52. Eulenstein, A.R.; Franzke, Y.J.; Lichtenberger, N.; Wilson, R.J.; Deubner, H.L.; Kraus, F.; Clérac, R.; Weigand, F.; Dehnen, S. Substantial $\pi$-aromaticity in the anionic heavy-metal cluster [Th@Bi $\left.{ }_{12}\right]^{4-}$. Nat. Chem. 2021, 13, 149-155. [CrossRef]

53. Gardner, B.M.; Lewis, W.; Blake, A.J.; Liddle, S.T. Thorium Triamidoamine Complexes: Synthesis of an Unusual Dinuclear TuckIn-Tuck-Over Thorium Metallacycle Featuring the Longest Known Thorium- - -Alkyl Bond. Organometallics 2015, 34, $2386-2394$. [CrossRef]

54. Green, M.L.H.; Pratt, L.; Wilkinson, G. Biscyclopentadienylrhenium hydride. J. Chem. Soc. 1958, 3916-3922. [CrossRef]

55. Karunananda, M.K.; Mankad, N.P. Heterobimetalluc $\mathrm{H}_{2}$ Addition and Alkene/Alkane Elimination Reactions Related to the Mechanism of E-Selective Alkyne Semihydrogenation. Organometallics 2017, 36, 220-227. [CrossRef]

56. Pyykkö, P. Additive Covalent Radii for Single-, Double-, and Triple-Bonded Molecules and Tetrahedrally Bonded Crystals: A Summary. J. Phys. Chem. A 2015, 119, 2326-2337. [CrossRef] [PubMed]

57. Ostrowski, J.P.A.; Atkinson, B.E.; Doyle, L.R.; Wooles, A.J.; Kaltsoyannis, N.; Liddle, S.T. The Ditungsten Decacarbonyl Dianion. Dalton Trans. 2020, 49, 9330-9355. [CrossRef]

58. Oxford Diffraction/Agilent Technologies UK Ltd. CrysAlisPRO Version 39.46; Oxford Diffraction/Agilent Technologies UK Ltd.: Yarnton, UK, 2013.

59. Sheldrick, G.M. SHELXT-Integrated space-group and crystal structure determination. Acta Cryst. Sect. A 2015, 71, 3-8. [CrossRef]

60. Sheldrick, G.M. Crystal structure refinement with SHELXL. Acta Cryst. Sect. C 2015, 71, 3-8. [CrossRef]

61. Dolomanov, O.V.; Bourhis, L.J.; Gildea, R.J.; Howard, J.A.K.; Puschmann, H. OLEX2: A complete structure solution, refinement and analysis program. J. Appl. Cryst. 2009, 42, 339-341. [CrossRef]

62. Farugia, L.J. WinGX and ORTEP for Windows: An update. J. Appl. Cryst. 2012, 45, 849-854. [CrossRef]

63. Persistence of Vision Pty Ltd. Persistence of Vision (TM) Raytracer; Persistence of Vision Pty. Ltd.: Williamstown, Melbourne, VIC, Australia, 2020.

64. Fonseca Guerra, C.; Snijders, J.G.; Te Velde, G.; Baerends, E.J. Towards an order-N DFT Method. Theor. Chem. Acc. 1998, 99, 391-403. [CrossRef]

65. Te Velde, G.; Bickelhaupt, F.M.; Van Gisbergen, S.J.; Fonseca Guerra, A.C.; Baerends, E.J.; Snijders, J.G.; Ziegler, T. Chemistry with ADF. J. Comput. Chem. 2001, 22, 931-967. [CrossRef]

66. Van Lenthe, E.; Baerends, E.J.; Snijders, J.G. Relativistic regular two-component Hamiltonians. J. Chem. Phys. 1993, 99, 4597-4610. [CrossRef]

67. Van Lenthe, E.; Baerends, E.J.; Snijders, J.G. Relativistic total energy using regular approximations. J. Chem. Phys. 1994, 101, 9783-9792. [CrossRef]

68. Van Lenthe, E.; Ehlers, A.E.; Baerends, E.J. Geometry optimization in the Zero Order Regular Approximation for relativistic effects. J. Chem. Phys. 1999, 110, 8943-8953. [CrossRef]

69. Vosko, S.H.; Wilk, L.; Nusair, M. Accurate spin-dependent electron liquid correlation energies for local spin density calculations: A critical analysis. Can. J. Phys. 1980, 58, 1200-1211. [CrossRef]

70. Becke, A.D. Density-functional exchange-energy approximation with correct asymptotic behaviour. Phys. Rev. A 1988, 38, 3098. [CrossRef]

71. Perdew, J.P. Density-functional approximation for the correlation energy of the inhomogeneous electron gas. Phys. Rev. B 1986, 33, 8822. [CrossRef]

72. Portmann, S.; Luthi, H.P. MOLEKEL: An interactive molecular graphics tool. Chimia 2000, 54, 766-770. 